\title{
Article
}

\section{Rapid Detection of Pathogenic Bacteria by the Naked Eye}

\author{
Karthikeyan Kandasamy ${ }^{1,2}$, Miftakhul Jannatin ${ }^{1,2}$ (D) and Yu-Chie Chen ${ }^{1,2, *(D)}$ \\ 1 Department of Applied Chemistry, National Chiao Tung University, Hsinchu 300, Taiwan; \\ mirokarthik.c@nycu.edu.tw (K.K.); miftakhulj.ac07g@nctu.edu.tw (M.J.) \\ 2 Department of Applied Chemistry, National Yang Ming Chiao Tung University, Hsinchu 300, Taiwan \\ * Correspondence: yuchie@nctu.edu.tw; Tel.: +886-3-5131527; Fax: +886-3-5723764
}

check for updates

Citation: Kandasamy, K.; Jannatin, M.; Chen, Y.-C. Rapid Detection of Pathogenic Bacteria by the Naked Eye. Biosensors 2021, 11, 317. https: / / doi.org/10.3390/ bios11090317

Received: 3 August 2021

Accepted: 2 September 2021

Published: 6 September 2021

Publisher's Note: MDPI stays neutral with regard to jurisdictional claims in published maps and institutional affiliations.

Copyright: (c) 2021 by the authors. Licensee MDPI, Basel, Switzerland. This article is an open access article distributed under the terms and conditions of the Creative Commons Attribution (CC BY) license (https:/ / creativecommons.org/licenses/by/ $4.0 /)$.

\begin{abstract}
Escherichia coli O157:H7 and Staphylococcus aureus are common pathogens. Gram-negative bacteria, such as E. coli, contain high concentrations of endogenous peroxidases, whereas Grampositive bacteria, such as $S$. aureus, possess abundant endogenous catalases. Colorless $3,5,3^{\prime}, 5^{\prime}$ tetramethyl benzidine (TMB) changes to blue oxidized TMB in the presence of E. coli and a low concentration of $\mathrm{H}_{2} \mathrm{O}_{2}$ (e.g., $\sim 11 \mathrm{mM}$ ) at $\mathrm{pH}$ of 3. Moreover, visible air bubbles containing oxygen are generated after $S$. aureus reacts with $\mathrm{H}_{2} \mathrm{O}_{2}$ at a high concentration (e.g., $180 \mathrm{mM}$ ) at $\mathrm{pH}$ of 3 . A novel method for rapidly detecting the presence of bacteria on the surfaces of samples, on the basis of these two endogenous enzymatic reactions, was explored. Briefly, a cotton swab was used for collecting bacteria from the surfaces of samples, such as tomatoes and door handles, then two-step endogenous enzymatic reactions were carried out. In the first step, a cotton swab containing bacteria was immersed in a reagent comprising $\mathrm{H}_{2} \mathrm{O}_{2}(11.2 \mathrm{mM})$ and TMB for $25 \mathrm{~min}$. In the second step, the swab was dipped further in $\mathrm{H}_{2} \mathrm{O}_{2}(180 \mathrm{mM})$ at $\mathrm{pH} 3$ for $5 \mathrm{~min}$. Results showed that the presence of Gram-negative bacteria, such as $E$. coli with a cell number of $\geq \sim 10^{5}$, and Gram-positive bacteria, such as $S$. aureus with a cell number of $\geq \sim 10^{6}$, can be visually confirmed according to the appearance of the blue color in the swab and the formation of air bubbles in the reagent solution, respectively, within $\sim 30 \mathrm{~min}$. To improve visual sensitivity, we dipped the swab carrying the bacteria in a vial containing a growth broth, incubated it for $\sim 4 \mathrm{~h}$, and carried out the two-stage reaction steps. Results showed that bluish swabs resulting from the presence of E. coli O157: H7 with initial cell numbers of $\geq \sim 34$ were obtained, whereas air bubbles were visible in the samples containing $S$. aureus with initial cell numbers of $\geq \sim 8.5 \times 10^{3}$.
\end{abstract}

Keywords: endogenous enzymatic reactions; Escherichia coli; Staphylococcus aureus; cotton swab; tetramethyl benzidine; naked eye detection

\section{Introduction}

Foodborne illnesses caused by pathogenic bacteria can result in diarrhea, abdominal pain, nausea, fever, and even death [1-5], and these pathogens cannot be easily identified on the basis of these symptoms [3]. Foodborne illnesses are life-threatening to the elderly, children, or newborn babies because of their weak immune systems [4,5]. Bacterial infections caused by pathogenic bacteria, including Escherichia coli [6], Shigella soney [7], Listeria monocytogenes [8], Salmonella spp. [9], and Staphylococcus aureus [10], demonstrate high mortality rates [11]. Agricultural products, such as vegetables, are commonly linked to bacterial contamination [12-16]. Hundreds of thousands of foodborne pathogenic infection cases are reported every year [14]. Vegetables contaminated by bacteria, such as E. coli O157:H7, a Gram-negative bacterium, have led to several foodborne disease outbreaks [13]. S. aureus, a Gram-positive bacterium, is another common pathogen that can cause foodborne illnesses [15]. In addition to causing food poisoning, bacteria such as E. coli J96 can cause infectious diseases, such as urinary tract infections [16]. S. aureus is also a common pathogen that causes skin infections [17]. 
In general, different types of antibiotics are used to treat illnesses resulting from Grampositive and Gram-negative bacteria. Given that current industrial washing treatments for fruits and vegetables cannot guarantee $100 \%$ pathogen-free products [18], determining whether bacterial contamination originates from Gram-positive or Gram-negative bacteria is vital. Meaningful information necessary to medical treatment can be obtained by determining whether infections or contaminations are caused by either Gram-positive or Gram-negative bacteria. However, traditional bioassays that require overnight culture take at least $3-5$ days to identify bacteria in real-world samples $[19,20]$. Moreover, although molecular diagnostic tools, such as real-time polymerase chain reactions, have high sensitivity, their execution needs well-trained personnel to reduce the possibility of obtaining false-positive results [21]. Immunoassays are fast and sensitive, but their applicability is limited by the availability of antibodies for diverse bacterial targets [22]. Although Gram-staining can be easily used in identifying Gram-positive and Gram-negative bacteria, their results require examination via optical microscopy. Furthermore, false-positive Gram-staining results may be obtained because of high decolorization, excessive heat during fixation, insufficient crystal violet concentration, and Gram-staining-resistant bacteria [23-25]. Moreover, it is usually recommended that bacteria should be freshly harvested from overnight or extended 18-48 h cultures before Gram-staining [26]. Thus, a screening method that is based on naked-eye detection and has speed, reliability, and high sensitivity without requiring overnight culture is desirable.

Most Gram-negative bacteria, such as E. coli, contain high amounts of peroxidases [27], which have been used in catalyzing the conversion of colorless 3,5,3', $5^{\prime}$-tetramethyl benzidine (TMB) into visible oxidized TMB with a blue color in the presence of $\mathrm{H}_{2} \mathrm{O}_{2}$ [26-29]. Supporting Information Scheme S1 in the Supplementary Materials shows the peroxidase reaction when TMB is used as a substrate in the presence of $\mathrm{H}_{2} \mathrm{O}_{2}$. At this point, the color of the resultant reaction is blue, whereas the reaction color changes to yellow when sulfuric acid is added to stop the reaction [30]. Owing to the existence of endogenous peroxidases in E. coli $\mathrm{O} 157: \mathrm{H7}$, peroxidase-based colorimetric reactions have generally been used in determining the presence of $E$. coli O157:H7 under standard buffer conditions at the lowest detectable concentration of $\sim 10^{5} \mathrm{cfu} \mathrm{mL}^{-1}$ [31]. However, most existing methods that use peroxidases for the visualization of the presence of Gram-negative bacteria still require overnight culture before peroxidase reaction tests can be carried out [32-36]. Moreover, Gram-positive bacteria, such as S. aureus, contain abundant catalases [37] that can catalyze the generation of oxygen in the presence of $\mathrm{H}_{2} \mathrm{O}_{2}$ [37] (SI Scheme S1). Satisfactory results, in which the limit of detection (LOD) of E. coli O157: H7 is as low as $\sim 10^{3}-10^{4} \mathrm{cfu} \mathrm{mL}^{-1}$, can be obtained after $4-6 \mathrm{~h}$ of bacterial culture before PCR analysis [38]. However, PCR analysis is time-consuming and labor-intensive because tedious sample pretreatment steps must be completed before the analysis can be performed [38].

Cotton swabs are useful tools for collecting trace samples from the surfaces of target samples [39]. Thus, we developed a rapid sensing method for detecting Gram-negative and Gram-positive, catalase-positive bacteria in samples by using cotton swabs as the tool. In this method, a swab is used as a sampling and sensing probe, and endogenous enzymatic reactions derived from target bacteria are used for distinguishing the presence of bacteria. The feasibility of using the swab-based testing approach in distinguishing Gram-negative bacteria from Gram-positive bacteria was demonstrated. The optimal experimental conditions were then examined, and cherry tomatoes and door handles contaminated by bacteria were used as real samples.

\section{Methods}

\subsection{Materials and Reagents}

Monopotassium phosphate, di-sodium phosphate, TMB, and phosphoric acid were purchased from Sigma-Aldrich (St. Louis, MO, USA). Potassium chloride was purchased from Fluka (Muskegon, MI, USA). Sodium dihydrogen phosphate hydrate was purchased from Mallinckrodt (St. Louis, MO, USA). Hydrochloric acid and sodium hydroxide were 
obtained from J. T. Baker (Phillipsburg, NJ, USA). Hydrogen peroxide was purchased from Showa (Tokyo, Japan). Cotton swabs were obtained from a local shop. Agarose was purchased from Amresco (Solon, OH, USA). Tryptic soy broth (TSB) and yeast extract (Y) were purchased from Becton Dickinson (Franklin Lakes, NJ, USA), whereas the LuriaBertani (LB) powder was purchased from Neogen (Lansing, MI, USA). E. coli J96 was kindly provided by Dr. James Johnson (Minneapolis Veterans Affairs Medical Center and the University of Minnesota, USA). Klebsiella pneumoniae, Pseudomonas aeruginosa, Staphylococcus aureus, Streptococcus pyogenes, and Enterococcus faecalis were collected from the patients in Hualien Tzu-Chi Hospital and kindly provided by Prof. P.-J. Tsai (National Cheng-Kung University, Taiwan). E. coli O157:H7 (BCRC 13085), Bacillus cereus (BCRC 17427), and Aspergillus niger (BCRC30130) were purchased from the Bioresource Collection and Research Center (Hsinchu, Taiwan). Cherry tomatoes were purchased from a local market.

\subsection{Instrumentation}

All the ultraviolet-visible (UV-Vis) absorption spectra were obtained using a Cary 50 UV-Vis absorption spectrophotometer from Varian (Melbourne, Australia). Cell images were obtained using an Eclipse 80i fluorescent microscope from Nikon (Tokyo, Japan).

\subsection{Preparation of Bacterial Samples}

All the Gram-positive and Gram-negative bacteria used in this study were Risk Group 2 pathogens. Thus, they were prepared in a Biosafety Level 2 laboratory. Gram-negative bacteria, including E. coli O157:H7, K. pneumoniae, and P. aeruginosa, were used as the model bacteria and cultured in LB broth at $37^{\circ} \mathrm{C}$ for $12 \mathrm{~h}$. LB broth $(10 \mathrm{~mL})$ was prepared by dissolving LB powder $(10 \mathrm{~g})$ in deionized water $(400 \mathrm{~mL})$. Gram-positive bacteria, including S. aureus, E. faecalis, B. cereus, and S. pyogenes, were selected as model bacteria and cultured in TSBY broth $(10 \mathrm{~mL})$ at $37^{\circ} \mathrm{C}$ for $12 \mathrm{~h}$. The TSBY broth was prepared by dissolving TSB $(12 \mathrm{~g})$ and $\mathrm{Y}(2 \mathrm{~g})$ in deionized water $(400 \mathrm{~mL})$. The resultant bacterial samples $(10 \mathrm{~mL})$ were centrifuged at $3750 \times g$ (rotor radius: $93 \mathrm{~mm}$ ) for $10 \mathrm{~min}$. The precipitated bacterial cells were rinsed with phosphate-buffered saline (PBS) solution $(\mathrm{pH} 7,1 \mathrm{~mL} \times 3)$ under centrifugation at $3750 \times g$ for $10 \mathrm{~min}$. PBS was prepared by dissolving sodium chloride $(400 \mathrm{mg})$, potassium chloride $(10 \mathrm{mg})$, disodium hydrogen phosphate $(57.5 \mathrm{mg})$, and potassium dihydrogen phosphate $(12 \mathrm{mg})$ in deionized water $(50 \mathrm{~mL})$. The $\mathrm{pH}$ of the solution was then adjusted to 7 . Stock bacterial suspension was prepared in PBS (pH 7) with optical density (OD) at the wavelength of $600 \mathrm{~nm}\left(\mathrm{OD}_{600}\right)$ of $\sim 1$. Bacterial samples with different concentrations were prepared with serial dilutions from the stock suspension.

\subsection{Endogenous Peroxidase and Catalase Reactions of Bacteria}

The endogenous peroxidase reactions of bacteria were analyzed by reacting model bacteria at a given concentration (e.g., $\mathrm{OD}_{600}$ of $~ 1$ ) prepared in the phosphate buffer ( $\mathrm{pH} 3,0.2 \mathrm{~mL}$ ) with $\mathrm{H}_{2} \mathrm{O}_{2}$ at different concentrations (5.6-2890 mM) and TMB (1.25 mM). Phosphate buffer at $\mathrm{pH} 3$ was prepared by adding monosodium dihydrogen phosphate hydrate $(53 \mathrm{mg})$ and disodium hydrogen phosphate pentahydrate $(165 \mathrm{mg})$ in deionized water $(50 \mathrm{~mL})$. The $\mathrm{pH}$ of the solution was then adjusted using phosphoric acid. The mixture containing bacteria and reagents with a low concentration of $\mathrm{H}_{2} \mathrm{O}_{2}$ was left standing for $25 \mathrm{~min}$ during peroxidase reactions and subsequently for catalase reaction, by adding $\mathrm{H}_{2} \mathrm{O}_{2}$ at a high concentration for another $5 \mathrm{~min}$. The resultant sample was examined by the naked eye and UV-Vis absorption spectroscopy.

\subsection{A Two-Step Method for Distinguishing Gram-Positive from Gram-Negative Bacteria}

Distinguishing bacteria based on their endogenous enzymatic reactions was performed by reacting model bacteria with $\mathrm{H}_{2} \mathrm{O}_{2}$ in the presence of TMB. Model bacteria, including Gram-positive and Gram-negative bacteria with an $\mathrm{OD}_{600}$ of $\sim 1$, were prepared in the PBS buffer at pH 7. A cotton swab was used to sample the bacterial solution $(10 \mu \mathrm{L})$ 
followed by immersing the swab in the reagent $(50 \mu \mathrm{L})$ containing $\mathrm{H}_{2} \mathrm{O}_{2}(11.2 \mathrm{mM})$ and TMB $(1.25 \mathrm{mM})$, prepared in the phosphate buffer at $\mathrm{pH} 3$. The sample stood for $25 \mathrm{~min}$ to allow the reaction to be completed. A bluish color appeared on the resultant swab if the sample contained Gram-negative bacteria, whereas bubbles might be observed if trace Gram-positive bacteria were present in the sample. If no bubbles were observed in the sample, the sample was further supplemented with $\mathrm{H}_{2} \mathrm{O}_{2}(180 \mathrm{mM}, 0.1 \mathrm{~mL})$ prepared in phosphate buffer at $\mathrm{pH} 3.0$ for $5 \mathrm{~min}$. The resultant samples were examined by the naked eye and a photograph was taken with a camera.

\subsection{Using Cherry Tomatoes as the Simulated Real Sample}

Cherry tomatoes smeared with model bacteria were used as the simulated real samples. E. coli O157:H7 samples with different concentrations were prepared from the stock bacterial sample with $\mathrm{OD}_{600}$ of $1\left(\sim 6.8 \times 10^{8} \mathrm{cfu} \mathrm{mL}^{-1}\right)$, via a serial dilution with the PBS buffer at $\mathrm{pH}$ 7. The as-prepared bacterial samples $(50 \mu \mathrm{L})$ were spread on the surface of the cherry tomato. After drying, a cotton swab was imbued with the phosphate buffer at $\mathrm{pH} 3(10 \mu \mathrm{L})$, followed by picking up bacteria from the surface of the as-prepared cherry tomato. The resultant swab was dipped into the droplet $(50 \mu \mathrm{L})$ containing $\mathrm{H}_{2} \mathrm{O}_{2}(11.2 \mathrm{mM})$ and TMB $(1.25 \mathrm{mM})$ at $\mathrm{pH}$ 3. After reacting at room temperature for $25 \mathrm{~min}$, the swab was examined by the naked eye, and a photograph was taken with a camera. These results were used as the standards for comparison with the results obtained from the samples prepared in the following way. That is, another three replicated samples $(50 \mu \mathrm{L})$ containing E. coli O157: H7 $\left(\sim 6.8 \times 10^{7} \mathrm{cfu} \mathrm{mL}^{-1}\right)$ were individually smeared on the surface of three cherry tomatoes by an inoculation loop. The cherry tomatoes were then dried in an oven at $37^{\circ} \mathrm{C}$ for $30 \mathrm{~min}$. After drying, the sample from the cherry tomato was detected following the experimental steps stated above.

Alternatively, to improve detection sensitivity, the resultant cotton swab that was obtained after picking up bacteria from the surface of the sample was dipped in a vial containing nutrient medium, such as LB broth $(0.4 \mathrm{~mL})$, for $\sim 4 \mathrm{~h}$. The resultant bacterial cells in the vial were separated through centrifugation at $3750 \times g$ (rotor radius: $93 \mathrm{~mm}$ ) for $5 \mathrm{~min}$. The bacterial cells were resuspended in the phosphate buffer $(\mathrm{pH} 3,0.2 \mathrm{~mL})$ containing $\mathrm{H}_{2} \mathrm{O}_{2}(11.2 \mathrm{mM})$ and TMB $(1.25 \mathrm{mM})$, followed by incubation at room temperature for $25 \mathrm{~min}$. The resultant samples were treated with sulfuric acid $(2 \mathrm{M}, 2 \mu \mathrm{L})$ to stop the reaction. The resultant samples were then examined using UV-Vis absorption spectroscopy.

\subsection{Detection of Bacteria from Door Handles}

Door handles contaminated with model bacteria, such as E. coli J96 and S. aureus, were prepared and used to simulate real-world samples. Bacterial samples were prepared by serially diluting the stock bacterial samples at $\mathrm{OD}_{600}$ of 1 (E. coli $\mathrm{J} 96\left(\mathrm{OD}_{600}\right.$ of $\left.1=\sim 5.5 \times 10^{8} \mathrm{cfu} \mathrm{mL}{ }^{-1}\right)$; S. aureus samples $\left(\mathrm{OD}_{600}\right.$ of $\left.1=\sim 1.7 \times 10^{9} \mathrm{cfu} \mathrm{mL}^{-1}\right)$ ) were diluted to a given concentration. The samples, including E. coli J96 $\left(\sim 5.4 \times 10^{6} \mathrm{cfu} \mathrm{mL}^{-1}\right)$, S. aureus $\left(\sim 1.7 \times 10^{9} \mathrm{cfu} \mathrm{mL} L^{-1}\right)$, S. aureus $\left(\sim 1.7 \times 10^{7} \mathrm{cfu} \mathrm{mL}^{-1}\right)$, and a mixture of $S$. aureus $\left(\sim 1.7 \times 10^{8} \mathrm{cfu} \mathrm{mL}^{-1}\right)$ and E. coli J96 $\left(\sim 5.4 \times 10^{6} \mathrm{cfu} \mathrm{mL}^{-1}\right)$, were prepared. The as-prepared bacterial samples $(50 \mu \mathrm{L})$ were individually spread on the surfaces of door handles. The samples were then dried at room temperature. After drying, a phosphate buffer $(\mathrm{pH} 3,10 \mu \mathrm{L})$ was deposited on the surfaces of the door handle and swabbed with a cotton swab. The resultant swab was immersed into a reagent $\left(50 \mu \mathrm{L}\right.$ ) containing $\mathrm{H}_{2} \mathrm{O}_{2}$ (at a concentration of $11.2 \mathrm{mM})$ and TMB $(1.25 \mathrm{mM})$ at $\mathrm{pH} 3$. After $25 \mathrm{~min}$, the cotton swab was examined by the naked eye and a photograph was taken with a camera. The cotton swab was further dipped into a reagent containing $\mathrm{H}_{2} \mathrm{O}_{2}(180 \mathrm{mM}, 0.1 \mathrm{~mL})$ at $\mathrm{pH} 3$ for another $5 \mathrm{~min}$. The sample was then examined by the naked eye, and a photograph was taken with a camera.

In addition, we also directly collected samples from three door handles in the restroom of our building. Each time, we used two cotton swabs to collect samples from the same door handle. One swab was used for the two-step screening test using the method shown 
above. The other cotton swab was inoculated on an LB agar plate for 14-hour incubation at $37^{\circ} \mathrm{C}$.

\section{Results and Discussion}

\subsection{Endogenous Peroxidase Reactions Derived from Bacterial Samples}

Given that the goal of this study was to use endogenous enzymatic reactions derived from bacteria for distinguishing Gram-negative bacteria from Gram-positive bacteria, two common pathogenic bacteria, S. aureus and E. coli O157: H7, were initially selected as the models for investigation. TMB was used as the substrate. Supporting Information Scheme $\mathrm{S} 1$ shows the peroxidase and catalase reactions. Figure 1A shows the photograph of the cotton swabs obtained after picking up the model bacteria $\left(50 \mu \mathrm{L}, \mathrm{OD}_{600}=1\right)$, following reaction with TMB $(1.25 \mathrm{mM})$ in the presence of $\mathrm{H}_{2} \mathrm{O}_{2}(11.2 \mathrm{mM})$ at $\mathrm{pH}$ 3. The cotton swab at the bottom of the photograph was tainted with Gram-negative bacteria (E. coli O157:H7), whereas the cotton swab at the top of the photograph was shown after sampling Gram-positive bacteria (S. aureus) and remained colorless. Figure 1B shows the UV-Vis absorption spectra obtained after the two model bacteria samples $(0.2 \mathrm{~mL}$, $\left.\mathrm{OD}_{600}=1\right)$ were reacted with TMB $(1.25 \mathrm{mM})$ in the presence of $\mathrm{H}_{2} \mathrm{O}_{2}(11.2 \mathrm{mM})$ prepared in phosphate buffer at $\mathrm{pH} 3$, and the inset shows the corresponding photographs of the samples. The colorimetric response was due to the catalytic activity of the endogenous peroxidase, derived from the bacteria that had reacted with TMB. The blue color was observed only in the presence of Gram-negative bacteria (E. coli O157:H7), indicating that the endogenous peroxidase reaction could potentially be applied to distinguish Gramnegative bacteria from Gram-positive bacteria. Figure 1C,D shows the optical microscopic images of E. coli O157:H7 without and with the addition of the optimal concentration of $\mathrm{H}_{2} \mathrm{O}_{2}$, respectively. A ring derived from bacterial cells was observed in the optical image in Figure 1C. However, the bacterial cells were disrupted after the addition of $\mathrm{H}_{2} \mathrm{O}_{2}(11.2 \mathrm{mM}$, $2 \mu \mathrm{L}$ ), and the ring, consisting of bacterial cells, had disappeared (Figure 1D). The results were further confirmed by using transmission electron microscopy (TEM). Figure 1E,F show the TEM images of E. coli O157:H7 obtained before and after the addition of $\mathrm{H}_{2} \mathrm{O}_{2}$, respectively. Intact $E$. coli $\mathrm{O} 157: \mathrm{H7}$ cells were clearly observed prior to the addition of $\mathrm{H}_{2} \mathrm{O}_{2}$ (Figure 1E). However, debris derived from E. coli O157:H7 mainly dominated the TEM image (Figure 1F), indicating that the disruption of bacterial cells occurred after the addition of $\mathrm{H}_{2} \mathrm{O}_{2}$. These results suggested that $\mathrm{H}_{2} \mathrm{O}_{2}$ has permeated and disrupted the bacterial cells, resulting in the release of biomolecules, such as peroxidase and catalases, triggering enzymatic reactions.

\subsection{Optimization of Experimental Parameters}

We further investigated the optimal experimental conditions needed for bacterial endogenous peroxidase reactions in the presence of $\mathrm{H}_{2} \mathrm{O}_{2}$, with TMB as the substrate. E. coli $\mathrm{O} 157: \mathrm{H} 7$ was used as the model bacterium. Figure S1A shows the photograph of the samples containing E. coli O157:H7 $\left(0.2 \mathrm{~mL} ; \mathrm{OD}_{600}=\sim 1\right)$, TMB $(1.25 \mathrm{mM}), \mathrm{H}_{2} \mathrm{O}_{2}$ at different concentrations (1.4-722 mM), and with sulfuric acid (2 M, $2 \mu \mathrm{L})$ to stop the reaction. Figure S1B shows the corresponding UV-Vis absorption spectra of the resultant samples. The yellow color intensified as the concentration of $\mathrm{H}_{2} \mathrm{O}_{2}$ increased, but the sample became paler as the concentration of $\mathrm{H}_{2} \mathrm{O}_{2}$ exceeded $90 \mathrm{mM}$ and decreased to less than $2.4 \mathrm{mM}$. The optimal concentration of $\mathrm{H}_{2} \mathrm{O}_{2}$ was $\sim 11.2 \mathrm{mM}$. Presumably, alkyl hydroperoxide reductase (AhP), the major bacterial peroxidase for peroxidase reactions, was triggered at a lower concentration of $\mathrm{H}_{2} \mathrm{O}_{2}[37,38]$. However, $\mathrm{AhP}$ was inactivated at a high concentration of $\mathrm{H}_{2} \mathrm{O}_{2}$ because of a limited cell capacity to provide electrons for $\mathrm{H}_{2} \mathrm{O}_{2}$ reduction [39]. The reaction was conducted and examined under different $\mathrm{pH}$ conditions to investigate the $\mathrm{pH}$ effects. Figure $\mathrm{S} 1 \mathrm{C}$ shows the resultant $\mathrm{UV}-\mathrm{Vis}$ absorption spectra of the samples containing E. coli O157:H7 $\left(\mathrm{OD}_{600}=1,0.2 \mathrm{~mL}\right)$. The spectra were obtained after reaction with $\mathrm{H}_{2} \mathrm{O}_{2}(11.2 \mathrm{mM})$ and TMB $(1.25 \mathrm{mM})$ at different $\mathrm{pH}$ values for $25 \mathrm{~min}$, with the addition of sulfuric acid to stop the reaction. The inset shows the 
corresponding photographs of the resultant samples. The samples became yellow at $\mathrm{pH} 3$, 4, and 5. No apparent color change was observed at $\mathrm{pH} 2,6$, and 7. That is, the optimal reaction occurred at $\mathrm{pH} 3$. Presumably, $\mathrm{H}_{2} \mathrm{O}_{2}$ effectively penetrated the bacterial cells and reacted substantially with peroxidases under acidic conditions [40-42]. However, when the reaction solution was excessively acidic $(\mathrm{pH} 2)$, the enzymatic activity of peroxidase was suppressed. Therefore, no reactions occurred at $\mathrm{pH} 2$. Thus, $\mathrm{pH} 3$ was selected as the optimal reaction condition in subsequent studies. Moreover, the optimal reaction temperature was observed at $25^{\circ} \mathrm{C}$ (Figure S1D).

(A)

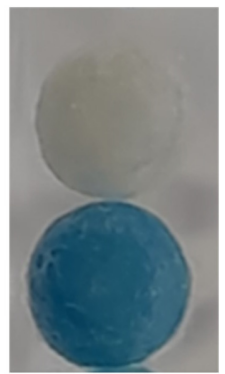

(C)

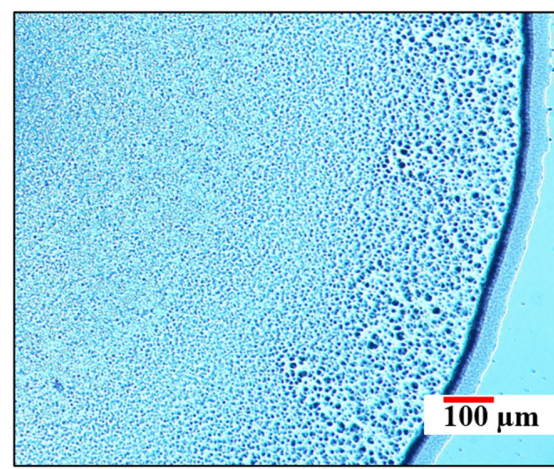

(E)

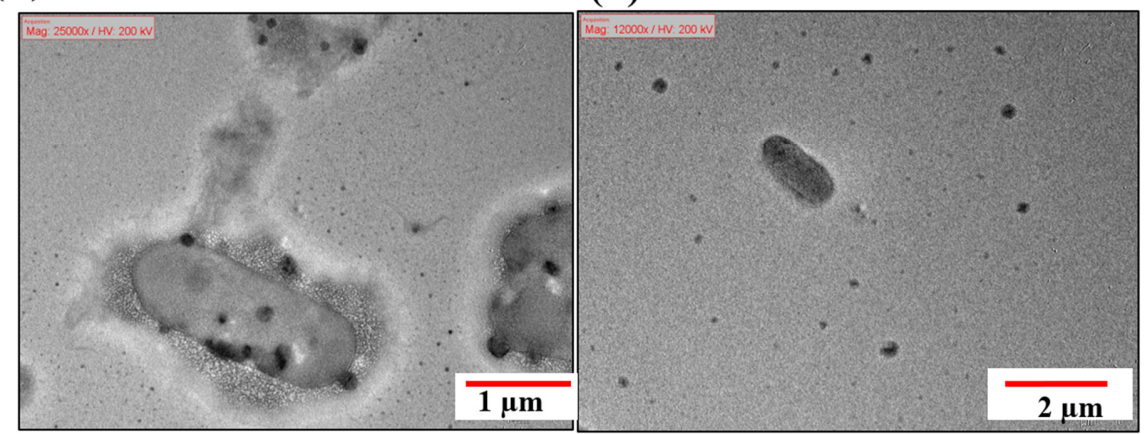

(B)

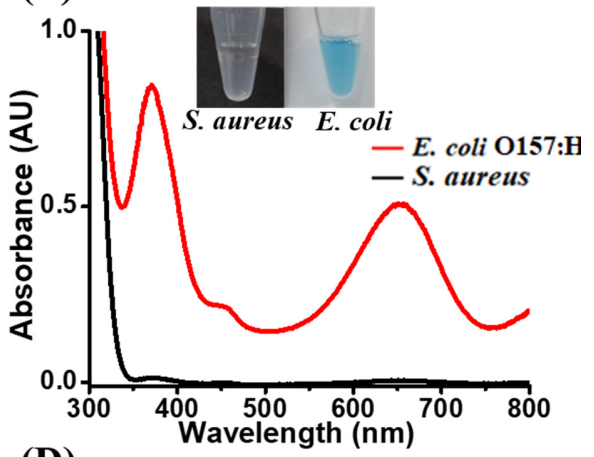

(D)

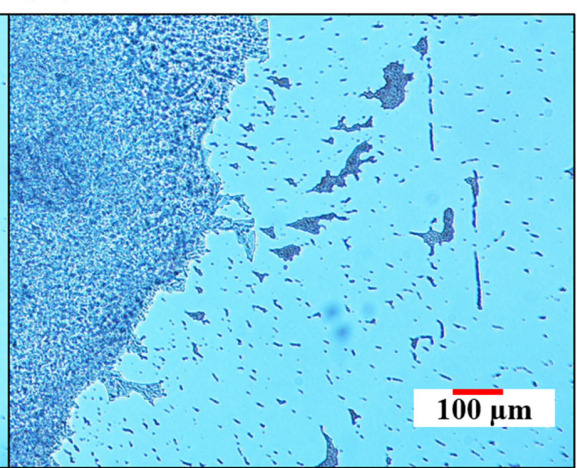

(F)

Figure 1. (A) Photographs of the cotton swabs obtained after sampling the bacterial samples $(50 \mu \mathrm{L})$ containing E. coli O157: $\mathrm{H} 7\left(\mathrm{OD}_{600}=\sim 1\right)$ and S. aureus $\left(\mathrm{OD}_{600}=\sim 1\right)$, after reacting with the reagent $(50 \mu \mathrm{L})$ containing TMB $(1.25 \mathrm{mM})$ and $\mathrm{H}_{2} \mathrm{O}_{2}(11.2 \mathrm{mM})$ at $\mathrm{pH} 3$ for $25 \mathrm{~min}$. (B) UV-Vis absorption spectra of the bacterial samples $(0.2 \mathrm{~mL})$ including E. coli O157: $\mathrm{H7}\left(\mathrm{OD}_{600}=1\right)$ and S. aureus $\left(\mathrm{OD}_{600}\right.$ =1) obtained after reaction with TMB and hydrogen peroxide $(11.2 \mathrm{mM})$ at $\mathrm{pH} 3$ for $25 \mathrm{~min}$, followed by the reaction with additional hydrogen peroxide $(7.2 \mathrm{M}, 5 \mu \mathrm{L})$ for another $5 \mathrm{~min}$. The inset shows the photographs of the resultant samples. Representative microscopic images of E. coli O157: H7 (C) without and (D) with the addition of $\mathrm{H}_{2} \mathrm{O}_{2}(11.2 \mathrm{mM}, 2 \mu \mathrm{L})$ at $\mathrm{pH}$ 3. The bacterial samples were stained with methylene blue ( $1 \mathrm{mM}, 2 \mu \mathrm{L})$ for $2 \mathrm{~min}$ before investigation by the optical microscope. (E,F) Corresponding TEM images of the samples shown in panels (C,D). 
The optimal reaction time for endogenous enzymatic reactions in the samples including E. coli O157:H7 and S. aureus (SI Figure S2A) was determined. The highest absorbance band was obtained after E. coli O157:H7 was reacted with TMB and $\mathrm{H}_{2} \mathrm{O}_{2}$ (11.2 mM) for 25 min (SI Figure S2A). Moreover, many bubbles derived from oxygen were observed from the sample containing $S$. aureus that was reacted with $\mathrm{H}_{2} \mathrm{O}_{2}(180 \mathrm{mM})$ for only $5 \mathrm{~min}$ (SI Figure S2B). These results indicated that the optimal reaction time for visual assessment of the color change from the endogenous peroxidase reaction derived from E. coli O157:H7 was $\sim 25 \mathrm{~min}$, whereas the optimal reaction time for visual assessment of the presence of $S$. aureus according to bubble formation was only $\sim 5 \mathrm{~min}$.

SI Figure S3 shows the photographs of the samples $(0.2 \mathrm{~mL})$ containing $S$. aureus $\left(\mathrm{OD}_{600}=\sim 1\right.$; Figure S3A) and E. coli O157:H7 ( $\mathrm{OD}_{600}=\sim 1$; Figure S3B) obtained after reaction with $\mathrm{H}_{2} \mathrm{O}_{2}$ at different concentrations (5.6-2890 mM), prepared in phosphate buffer at $\mathrm{pH}$ 3. Bubbles from the samples containing $S$. aureus were clearly observed after adding $\mathrm{H}_{2} \mathrm{O}_{2}$ at concentrations of $90-2890 \mathrm{mM}$, indicating that the activities of bacterial endogenous catalases were induced at a high concentration $(\geq 90 \mathrm{mM})$ of hydrogen peroxide (Figure S3A). The bubbles were not observed in the samples containing E. coli O157:H7 after the addition of $\mathrm{H}_{2} \mathrm{O}_{2}$ at concentrations of $\leq 180 \mathrm{mM}$ (Figure S3B). Nevertheless, intense color changes were visible in the samples containing E. coli O157:H7 that were reacted with TMB in the presence of $\mathrm{H}_{2} \mathrm{O}_{2}$ at concentrations of $\sim 6-90 \mathrm{mM}$ (cf. Figure S1A). According to the results shown in SI Figures S1 and S3, we concluded that the optimal concentration of $\mathrm{H}_{2} \mathrm{O}_{2}$ for revealing endogenous peroxidase activity derived from E. coli O157:H7 was $\leq 90 \mathrm{mM}$, whereas the concentration of $\mathrm{H}_{2} \mathrm{O}_{2}$ for triggering endogenous catalase activity derived from $S$. aureus was $\geq 90 \mathrm{mM}$. That is, endogenous peroxidase or catalase reactions could be observed by adjusting the concentration of $\mathrm{H}_{2} \mathrm{O}_{2}$ in the enzymatic reactions. Therefore, either Gram-positive, catalase-positive bacteria or Gram-negative bacteria can be distinguished, based on the color change or bubble formation, respectively, by adjusting the concentration of $\mathrm{H}_{2} \mathrm{O}_{2}$ in the endogenous enzymatic reaction.

Moreover, we also selected two more Gram-positive bacteria, i.e., B. cereus and E. faecalis, as the model samples, to examine whether bubbles were formed in the addition of $\mathrm{H}_{2} \mathrm{O}_{2}$. SI Figure $44 \mathrm{~A}$ shows the resultant photograph of the samples obtained after reacting with $\mathrm{H}_{2} \mathrm{O}_{2}$. Apparently, many bubbles were formed in the sample containing $B$. cereus, whereas bubbles were barely observed in the sample containing E. faecalis. This was understandable because E. faecalis is generally considered as a catalase-negative bacterium and may show weak catalase-positive activity only in specific conditions [43]. The results indicated that our method can be used to realize the presence of catalase-positive bacteria. In addition, two more Gram-negative bacteria, i.e., P. aeruginosa and K. pneumoniae, were selected as the model samples for endogenous peroxidase reactions. SI Figure S4B shows the resultant photographs of these two bacterial samples obtained after reacting with $\mathrm{TMB}$ in the presence of $\mathrm{H}_{2} \mathrm{O}_{2}$, followed by the addition of sulfuric acid to stop the reaction. Apparently, the color of the resultant samples became yellow, indicating the presence of peroxidase existing in these two Gram-negative bacteria. That is, our method can also be used to indicate the presence of these two Gram-negative bacteria, based on the color change. This is understandable because Gram-negative bacteria generally contain abundant peroxidases. These results indicated the suggested method can be used to rapidly distinguish the presence of Gram-negative bacteria. However, if the results showed no color change and no bubble formation, one should not exclude the possibility of the presence of Gram-positive, catalase negative bacteria. Moreover, distinguishing among different Gram-positive bacterial strains or different Gram-negative bacteria by the current method is not possible.

\subsection{Examination of the Lowest Detectable Concentration by the Naked Eye}

We further investigated the lowest detectable bacterial cell concentration using the developed method. E. coli O157:H7 and S. aureus were used as the model bacteria. Figure 2A shows the photograph of the cotton swabs imbued with E. coli O157:H7 samples $(50 \mu \mathrm{L}$ 
containing $\sim 2.7 \times 10^{4}-2.7 \times 10^{7}$ cells), prepared in the phosphate buffer at $\mathrm{pH} 3$ containing TMB $(1.25 \mathrm{mM})$ and $\mathrm{H}_{2} \mathrm{O}_{2}(11.2 \mathrm{mM})$. An apparent blue color appeared on the swab with the highest number of bacterial cells. When the amount of $E$. coli O157:H7 was dropped to $\sim 2.7 \times 10^{5}$, a pale bluish color on the swab was still visible, indicating that the lowest visualizable amount was $\sim 10^{5}$ bacterial cells. Figure 2B shows the UV-Vis absorption spectra of $E$. coli J96 sample in the phosphate buffer, with the same treatment as shown in Figure 2A. The maximum absorption band appeared at a wavelength of $\sim 650 \mathrm{~nm}$, in which the intensity was proportional to the cell concentration of E. coli O157:H7. Cotton swabs were used when sampling $S$. aureus from the samples $(50 \mu \mathrm{L})$ containing $8.5 \times 10^{4}-8.5 \times 10^{7}$ cells, prepared in the phosphate buffer at $\mathrm{pH} 3$ and then immersed in a reagent $(0.1 \mathrm{~mL})$ containing $\mathrm{H}_{2} \mathrm{O}_{2}(180 \mathrm{mM})$ prepared in the phosphate buffer at $\mathrm{pH} 3$. Figure $2 \mathrm{C}$ shows the resultant photograph, in which the bubbles containing oxygen increased with the concentration of $S$. aureus because of the endogenous catalase reaction (SI Scheme S1). In contrast, the endogenous reaction derived from $S$. aureus was directly conducted in a liquid reagent containing TMB $/ \mathrm{H}_{2} \mathrm{O}_{2}$. Figure 2D shows the photographs of the $S$. aureus samples $(0.1 \mathrm{~mL})$, containing $\sim 8.5 \times 10^{4}-8.5 \times 10^{7}$ cells, after reaction with $\mathrm{H}_{2} \mathrm{O}_{2}(180 \mathrm{mM})$ for $5 \mathrm{~min}$. Bubbles were observed in the samples containing $S$. aureus with a cell number of $\geq \sim 10^{6}$ cells, similar to those observed in Figure 2C. The results indicated that it was possible to visually assess the presence of Gram-positive bacteria such as S. aureus in the sample, based on the observation of bubbles.

(A)

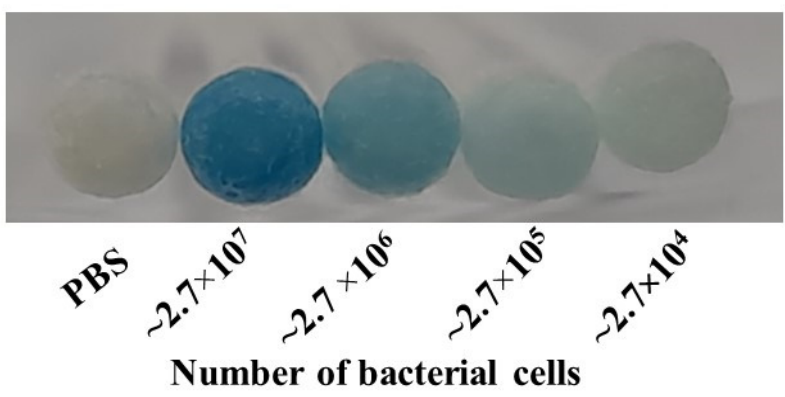

(C)

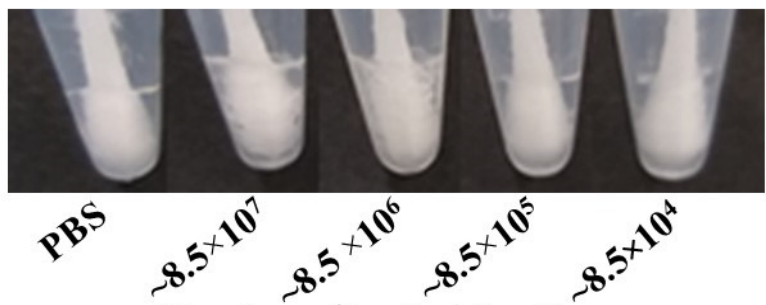

(B)

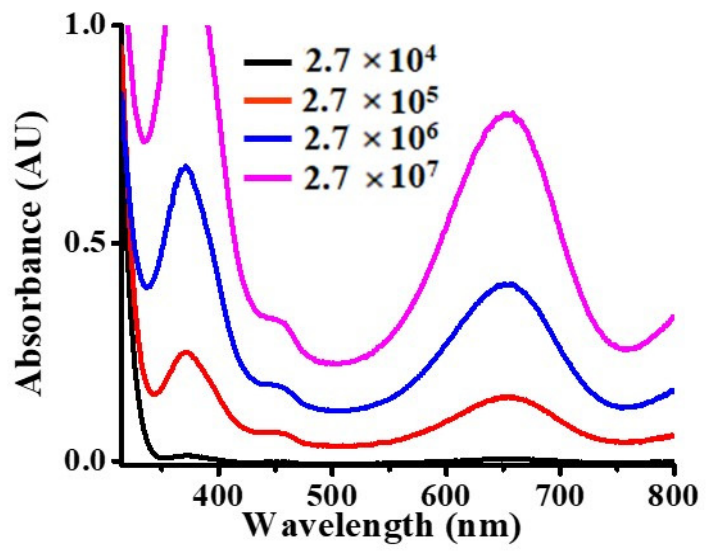

(D)

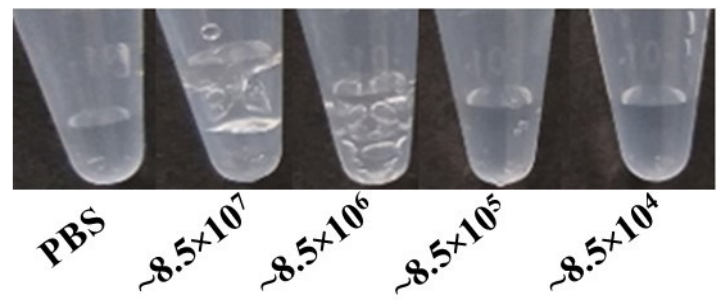

Number of bacterial cells

Figure 2. (A) Photograph of the cotton swabs obtained after imbuing with the samples $(10 \mu \mathrm{L})$ containing E. coli O157:H7 at concentrations of $\sim 5.4 \times 10^{5}-\sim 5.4 \times 10^{8} \mathrm{cfu} \mathrm{mL}^{-1}$ of bacterial cells, prepared at $\mathrm{pH} \mathrm{3,} \mathrm{followed} \mathrm{by} \mathrm{dipping} \mathrm{into} \mathrm{a}$ reagent droplet $(50 \mu \mathrm{L})$ consisting of TMB $(1.25 \mathrm{mM})$ and $\mathrm{H}_{2} \mathrm{O}_{2}(11.2 \mathrm{mM})$ at $\mathrm{pH}$ 3. (B) UV-Vis absorption spectra of the bacterial samples $(0.2 \mathrm{~mL})$ containing E. coli O157:H7 at concentrations of $\sim 5.4 \times 10^{5}-\sim 5.4 \times 10^{8} \mathrm{cfu} \mathrm{mL}^{-1}$ obtained after reaction with hydrogen peroxide $(\sim 11.2 \mathrm{mM})$ at $\mathrm{pH} 3(0.2 \mathrm{~mL})$ for $25 \mathrm{~min}$. (C) Photograph of the cotton swabs obtained after sampling $S$. aureus, at concentrations of $\sim 8.5 \times 10^{5}-\sim 8.5 \times 10^{8} \mathrm{cfu} \mathrm{\textrm {mL } ^ { - 1 }}$, from the samples $(0.1 \mathrm{~mL})$ prepared in the phosphate buffer at $\mathrm{pH} 3$, followed by the reaction with $\mathrm{H}_{2} \mathrm{O}_{2}(180 \mathrm{mM}, 0.1 \mathrm{~mL})$ at $\mathrm{pH}$ 3. (D) Photograph of the bacterial samples $(0.1 \mathrm{~mL})$ containing $S$. aureus at concentrations of $\sim 8.5 \times 10^{5}-\sim 8.5 \times 10^{8} \mathrm{cfu} \mathrm{mL} \mathrm{m}^{-1}$ cells obtained after reaction with hydrogen peroxide $(180 \mathrm{mM}, 0.1 \mathrm{~mL})$ prepared in the phosphate buffer at $\mathrm{pH} 3$ for $5 \mathrm{~min}$. 


\subsection{Examination of Selectivity}

The performance of the current approach in discriminating between Gram-positive and Gram-negative bacteria was evaluated. Gram-positive bacteria, including S. aureus, $S$. pyogenes, B. cereus, and E. faecalis, and Gram-negative bacteria, including E. coli O157:H7, P. aeruginosa, and K. pneumoniae, were used as the model bacteria. Figure 3A shows the UV-Vis absorption spectra of the samples $\left(0.2 \mathrm{~mL}, \mathrm{OD}_{600}=\sim 1\right)$ containing E. coli O157:H7, $S$. aureus, B. cereus, S. pyogenes, and E. faecalis with the same $\mathrm{OD}_{600}$ at $\sim 1$, after reaction with TMB $(1.25 \mathrm{mM})$, in the presence of $\mathrm{H}_{2} \mathrm{O}_{2}(11.2 \mathrm{mM})$ prepared in phosphate buffer at $\mathrm{pH} 3$ and the subsequent addition of sulfuric acid to stop the reaction. Only the sample containing E. coli O157:H7 showed an absorption band at a wavelength of $\sim 450 \mathrm{~nm}$. The samples containing Gram-positive bacteria did not have any apparent absorption band, indicating that they did not have sufficient peroxidase to carry out enzymatic reactions. Figure 3B shows the photographs of the samples $(0.2 \mathrm{~mL})$ containing S. aureus, E. coli O157:H7, K. pneumoniae, and P. aeruginosa that were obtained after reaction with $\mathrm{H}_{2} \mathrm{O}_{2}$ $(180 \mathrm{mM})$ prepared in phosphate buffer at $\mathrm{pH} 3$. Apparently, only the sample containing S. aureus showed observable bubbles, indicating that the bacterial endogenous catalase reaction was triggered. The rest of the samples did not show any bubbles, indicating that there was not good catalase activity with $\mathrm{H}_{2} \mathrm{O}_{2}(180 \mathrm{mM})$. That is, the results demonstrated that Gram-positive or Gram-negative bacteria in a sample could be detected by adding different concentrations of $\mathrm{H}_{2} \mathrm{O}_{2}$. Bubble formation and color changes can be used as indicators for detecting Gram-positive bacteria and Gram-negative bacteria, respectively.

(A)

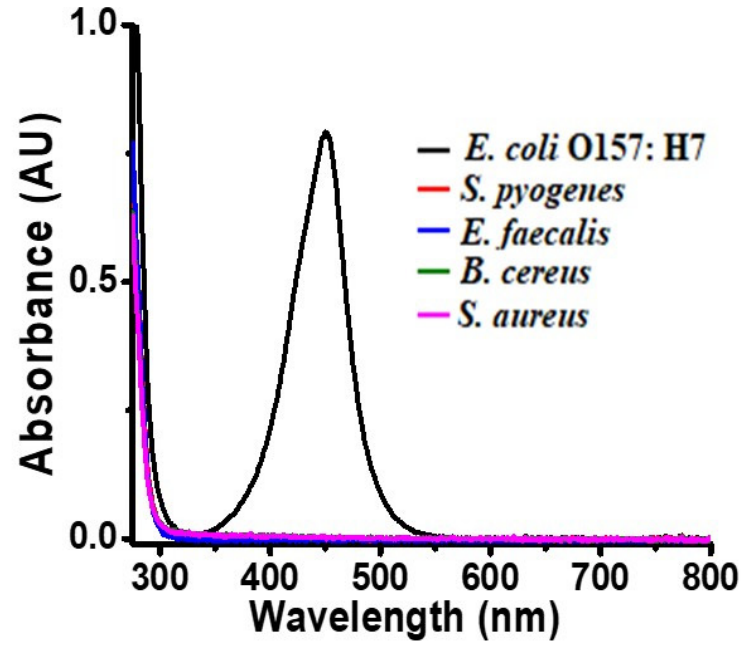

(B)

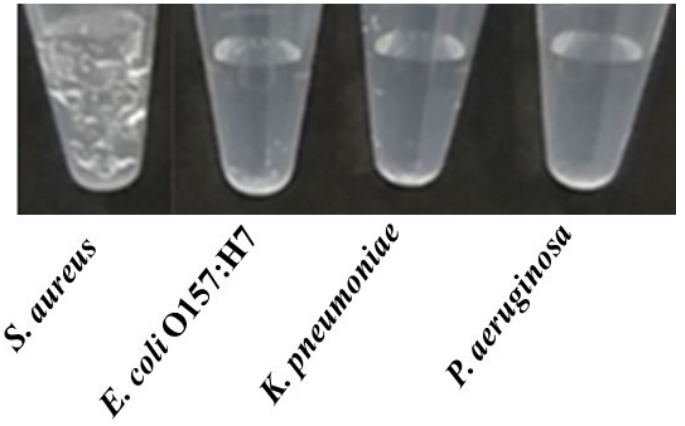

Figure 3. Examination of selectivity. (A) UV-Vis absorption spectra of the samples $(0.2 \mathrm{~mL})$ containing E. coli O157:H7, S. aureus, B. cereus, S. pyogenes, and E. faecalis prepared in the phosphate buffer at $\mathrm{pH}$; spectra were obtained after reaction with TMB $(1.25 \mathrm{mM})$ in the presence of $\mathrm{H}_{2} \mathrm{O}_{2}(\sim 11.2 \mathrm{mM})$ for $25 \mathrm{~min}$, followed by the addition of sulfuric acid $(2 \mathrm{M}, 2 \mu \mathrm{L})$ to stop the reaction. All the model bacteria had the cell concentration of $\mathrm{OD}_{600}$ equal to $\sim 1$. (B) Photograph of the samples $(0.2 \mathrm{~mL})$ containing S. aureus, E. coli O157:H7, K. pneumoniae, and P. aeruginosa (from left to right) prepared in the phosphate buffer at $\mathrm{pH} 3$ and obtained after reaction with $\mathrm{H}_{2} \mathrm{O}_{2}(180 \mathrm{mM})$ for $5 \mathrm{~min}$. All the model bacteria had a cell concentration of $\mathrm{OD}_{600}$ equal to $\sim 1$.

\subsection{Analysis of Different Strains of E. coli}

Different strains of E. coli, including E. coli JM109, E. coli J96, E. coli O78:H11, and E. coli BOS 117 were also used as the model bacteria, to examine whether the current approach was effective for these different E. coli strains. E. coli O157:H7 was also examined again for comparison. The optimal reaction conditions obtained above were applied to conduct the reaction. The inset in Figure 4 shows the photographs of the resultant samples of different E. coli strains were obtained after reacting with TMB in the presence of hydrogen peroxide. All the cotton swabs became blue, indicating that the method can be used to sense the presence of different E. coli strains. Figure 4 shows the resultant UV-Vis absorption spectra 
of these E. coli samples, obtained after the reaction with TMB in the presence of hydrogen peroxide, followed by the addition of sulfuric acid to stop the reaction. The maximum absorbance band at the wavelength of $450 \mathrm{~nm}$ among different $E$. coli strains looked similar, indicating that these E. coli strains had similar responses to the endogenous peroxidase reaction.

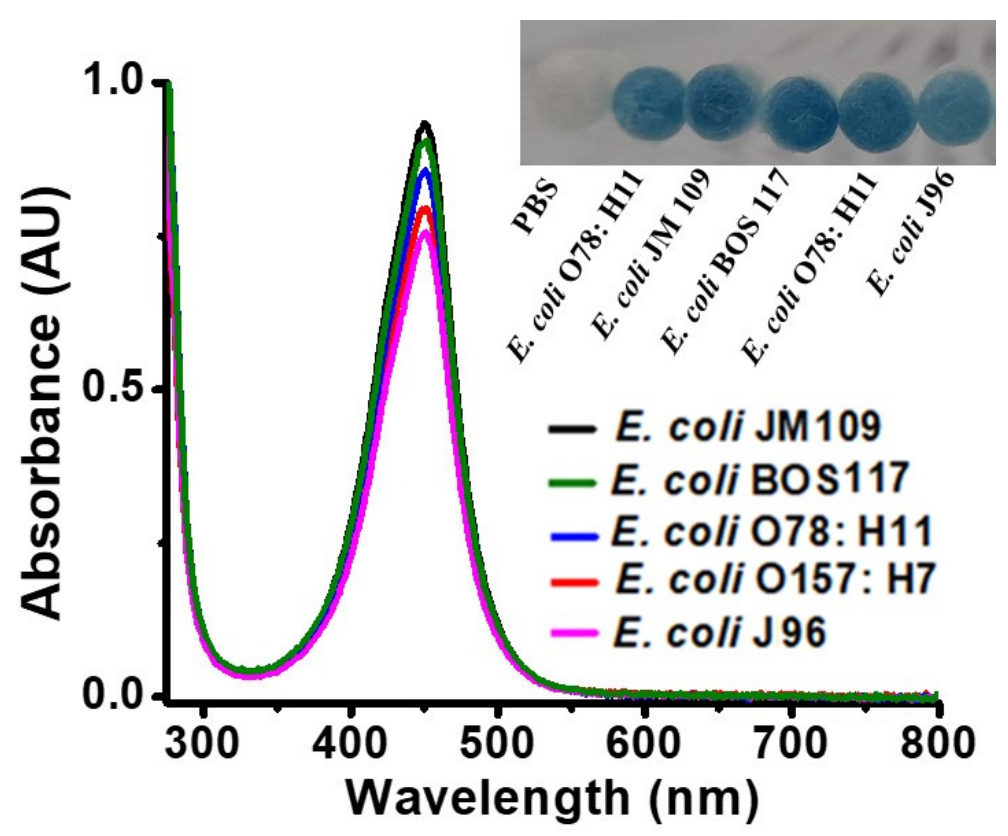

Figure 4. UV-Vis absorption spectra of the samples $(0.2 \mathrm{~mL})$ containing different $E$. coli strains $\left(\mathrm{OD}_{600}\right.$ of $\left.\sim 1\right)$, obtained after reaction with $\mathrm{H}_{2} \mathrm{O}_{2}(11.2 \mathrm{mM})$ in the presence of TMB $(1.25 \mathrm{mM})$ at $\mathrm{pH} 3$, followed by the addition of sulfuric acid $(2 \mathrm{M}, 2 \mu \mathrm{L})$ to stop the reaction. (Inset) shows the photograph of the cotton swabs containing E. coli strains $\left(\mathrm{OD}_{600}\right.$ of $\left.\sim 1\right)$ obtained after reaction with $\mathrm{H}_{2} \mathrm{O}_{2}(11.2 \mathrm{mM})$ in the presence of TMB $(1.25 \mathrm{mM})$ at $\mathrm{pH}$ 3. The reaction was conducted at room temperature $\left(\sim 25^{\circ} \mathrm{C}\right)$.

\subsection{Examination of Interference Effects}

Whether the results were affected by the presence of sodium chloride, potassium chloride, creatinine, bovine serum albumin, and histamine, which are commonly present in real-world samples, was determined by conducting sensing experiments in the presence of these species. Because the concentrations of these selected interference species usually are not over $1 \mathrm{mM}$ in real samples, $1 \mathrm{mM}$ of each interference species was used for the preparation of the samples. E. coli O157:H7 was used as the model bacterium. Figure 5A shows the UV-Vis absorption spectra of the samples containing E. coli O157:H7 after the addition of sodium chloride $(1 \mathrm{mM})$, potassium chloride $(1 \mathrm{mM})$, creatinine $(1 \mathrm{mM})$, bovine serum albumin $(1 \mathrm{mM})$, and histidine $(1 \mathrm{mM})$. The intensities of the maximum absorption at the wavelength of $\sim 450 \mathrm{~nm}$ in all the absorption spectra were highly similar, indicating that the reaction was not considerably affected by the presence of the additives. Whether the bacterial catalase reaction itself was affected was determined by examining samples containing S. aureus and the same interference species as used above. Figure $5 \mathrm{~B}$ shows the photographs of the samples. Apparently, all the samples generated observable bubbles, indicating that the additives did not affect the endogenous catalase reactions. 
(A)

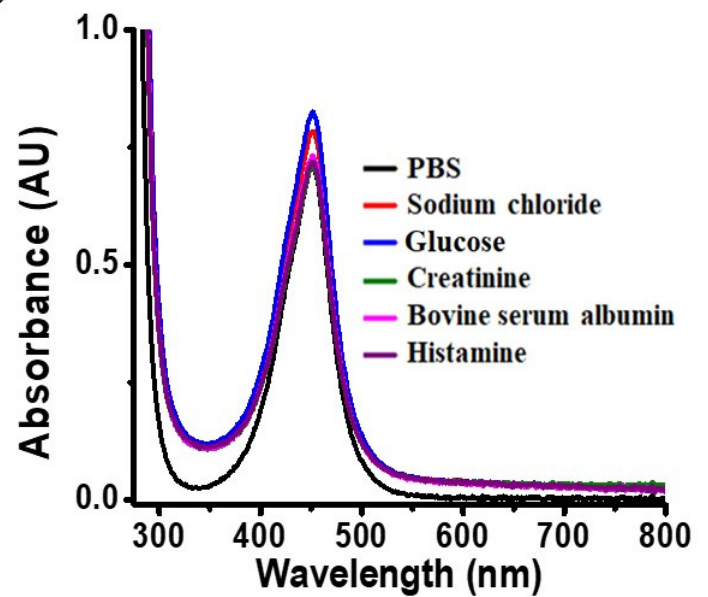

(B)

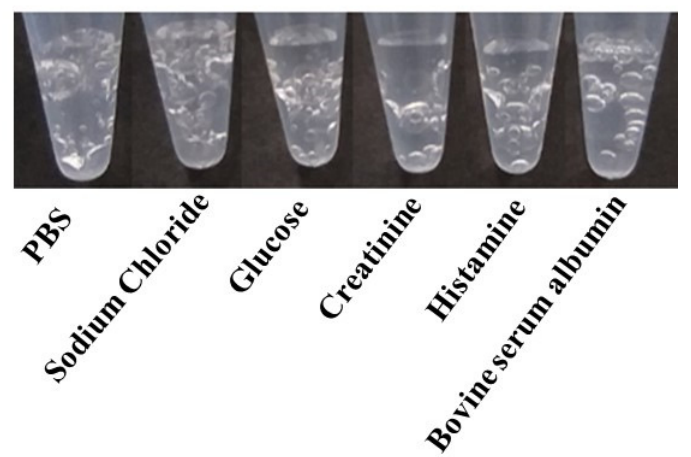

Figure 5. Examination of interference species effects. (A) UV-Vis absorption spectra of the samples (0.2 mL) containing E. coli $\mathrm{O} 157: \mathrm{H7}\left(\mathrm{OD}_{600}=\sim 1\right)$ with the inferences species including sodium chloride $(1 \mathrm{mM})$, potassium chloride $(1 \mathrm{mM})$, creatinine $(1 \mathrm{mM})$, bovine serum albumin $(1 \mathrm{mM})$, and histamine $(1 \mathrm{mM})$ obtained after reaction with $\mathrm{H}_{2} \mathrm{O}_{2}(11.2 \mathrm{mM})$ and TMB (1.25 mM) for $25 \mathrm{~min}$ followed by the addition of sulfuric acid ( $2 \mathrm{M}, 2 \mu \mathrm{L})$ to stop the reaction. All the samples were prepared in the phosphate buffer at $\mathrm{pH}$ 3. (B) Photograph of the samples $(0.2 \mathrm{~mL})$ containing . aureus $\left(\mathrm{OD}_{600}=1\right)$ with interferences including sodium chloride $(1 \mathrm{mM})$, potassium chloride $(1 \mathrm{mM})$, creatinine $(1 \mathrm{mM})$, bovine serum albumin $(1 \mathrm{mM})$, and histidine $(1 \mathrm{mM})$, obtained after the reaction with $\mathrm{H}_{2} \mathrm{O}_{2}(180 \mathrm{mM})$ for $5 \mathrm{~min}$.

Although this study emphasized the discrimination of Gram-positive bacteria and Gram-negative bacteria, we also considered the interference from other microorganisms such as fungi. For example, $A$. niger, which generates black spores, also contains abundant catalases [44]. Thus, bubble formation may be observed when a number of spores are present in the sample using our method. Figure S6A shows the photograph of the samples including the mixtures of E. coli $\mathrm{O} 157: \mathrm{H7}\left(\mathrm{OD}_{600}\right.$ of $\left.\sim 1\right)$ and A. niger spores, at concentrations of $\mathrm{OD}_{600}$ of $\sim 1, \sim 0.1$, and $\sim 0.01$ (left to right), as obtained after reaction with TMB in the presence of $\mathrm{H}_{2} \mathrm{O}_{2}(\sim 11.2 \mathrm{mM})$. Figure $\mathrm{S} 6 \mathrm{~B}$ shows the same samples used for Figure S6A with the further addition of $\mathrm{H}_{2} \mathrm{O}_{2}(180 \mathrm{mM})$. The results shown in Figure S6A,B bore a close resemblance. Apparently, the samples became blue owing to the presence of $E$. coli O157:H7, whereas bubbles were observed in some sample vials. The number of bubbles decreased as the concentration of $A$. niger decreased. Moreover, black spores were apparently visible in the samples containing $A$. niger at concentrations of $\mathrm{OD}_{600}$ of $\sim 1$ and $\sim 0.1$. Although bubbles were formed in the samples containing $A$. niger, the concentration of $A$. niger needed to reach $\mathrm{OD}_{600} \geq \sim 0.1$ to be observed easily. On the other hand, we were able to realize the presence of black spores at a concentration of $\mathrm{OD}_{600} \geq \sim 0.1$ by the naked eye. However, unlike fungi, the assay developed in this study was required to determine the presence of Gram-positive and Gram-negative bacteria in the samples, owing to the small size and invisibility of bacterial cells. The results indicated that the presence of $A$. niger at a concentration higher than $\sim 0.1$ in the sample can also generate bubbles using our method, which may lead to misdiagnosis of the presence of Gram-positive bacteria. Nevertheless, one can realize the presence of fungi at $\mathrm{OD}_{600}$ higher than $\sim 0.1$ without conducting additional endogenous enzymatic reactions, because of the visible fungal spores.

\subsection{Analysis of Real Samples}

We further investigated the feasibility of using our approach in the direct detection of bacteria in simulated real samples. E. coli O157:H7 may contaminate vegetables or fruits, such as tomatoes. Thus, cherry tomatoes were selected as model samples for the preparation of simulated real samples. We smeared trace bacteria (E. coli O157:H7) on the surface of an intact tomato. The samples containing E. coli O157:H7 with different concentrations were prepared by serially diluting an E. coli O157:H7 suspension, with an 
$\mathrm{OD}_{600}$ value of 1 , four times with a dilution factor of 10 . Figure $6 \mathrm{~A}$ shows the photographs of the cotton swabs, obtained after E. coli O157:H7 samples $(10 \mu \mathrm{L})$ with a cell number ranging from $\sim 3.4 \times 10^{4}$ to $\sim 3.4 \times 10^{7}$ cells were collected and immersed in a reagent droplet $(50 \mu \mathrm{L})$ containing $\mathrm{H}_{2} \mathrm{O}_{2}$ and TMB. The experimental details are described in the Experimental Section. The blue color of the swab became pale as the number of bacterial cells decreased. We were still able to see a pale bluish discoloration on the swab at a cell number of $\sim 10^{5}$. We further prepared three cherry tomatoes smeared with trace bacteria ( $E$. coli O157:H7; $50 \mu \mathrm{L} ; \sim 6.8 \times 10^{7} \mathrm{cfu} \mathrm{mL}^{-1}$; Figure $6 \mathrm{~B}$ ). After the bacterial sample was dried on the cherry tomato, a cotton swab was used in collecting bacteria from the surface. The cotton swab was then immersed in a reagent droplet $(50 \mu \mathrm{L})$ containing $\mathrm{H}_{2} \mathrm{O}_{2}(11.2 \mathrm{mM})$ and TMB $(1.25 \mathrm{mM})$ at $\mathrm{pH} 3$. The inset photographs show the resultant swabs from three replicated experiments. Compared with the results shown in Figure $6 \mathrm{~A}$, the bacterial sample from the peel of an individual cherry tomato was $\sim 10^{6}$ cells. That is, the current approach can be used in roughly estimating bacterial cell numbers according to color changes from the results obtained in standard samples. However, directly observing the presence of E. coli O157: H7 with a cell number below $\sim 10^{5}$ cells is impossible using this approach. Nevertheless, given that $E$. coli can divide into two cells every 4-20 min under nutrient-rich and aerobic environmental conditions [45], $4 \mathrm{~h}$ of incubation should be enough to generate sufficient bacterial cells for visual assessment with our method. Thus, the sample was further incubated in a growth medium for another $4 \mathrm{~h}$ before the enzymatic reaction. Figure $6 \mathrm{C}$ shows the photographs of the samples obtained from the surfaces of intact cherry tomatoes smeared with E. coli O157:H7, with cell numbers of $\sim 3.4 \times 10^{4}, \sim 3.4 \times 10^{3}, \sim 3.4 \times 10^{2}$, and $\sim 3$, followed by 4-hour incubation and peroxidase reactions. Sulfuric acid was used to stop the reaction. Figure $6 \mathrm{D}$ shows the corresponding UV-Vis absorption of the same samples in Figure 6C. According to these results, the lowest detectable cell number was $\sim 34$. In addition, we also investigated whether the sensitivity of our method toward S. aureus could be further improved by incubating the swabs that were tainted with $S$. aureus at different cell numbers, followed by 4-hour incubation and endogenous enzymatic reactions. SI Figure S5 shows a photograph of the resultant samples. Apparently, air bubbles were still observable in the samples with initial bacterial cells to $\geq \sim 8.5 \times 10^{3}$. No bubbles were observed when the cell number was reduced to $\sim 850$. The analysis time, including bacterial incubation, was $\sim 4.5 \mathrm{~h}$, which was considerably shorter than that needed for conventional overnight culture bioassays. However, the detectable bacterial cell numbers in the samples containing E. coli O157:H7 and S. aureus were reduced to few tens and few thousands, respectively.

E. coli and S. aureus are common pathogens and may be commonly found on door handles. Thus, door handles contaminated with E. coli $\mathrm{J} 96$ and S. aureus were prepared. We smeared trace amounts of bacteria, including E. coli J96 and S. aureus, on the surfaces of door handles. The experimental details are described in Section 2.7. Figure 7A shows the photographs of the cotton swabs obtained from the door handle samples spiked with $E$. coli J96, a mixture of E. coli J96 and S. aureus, and two samples of S. aureus. All samples were reacted with a reagent $(50 \mu \mathrm{L})$ containing $\mathrm{H}_{2} \mathrm{O}_{2}(11.2 \mathrm{mM})$ and TMB $(1.25 \mathrm{mM})$ prepared in phosphate buffer at $\mathrm{pH} 3$ for $25 \mathrm{~min}$. Figure 7B shows the photograph of the resultant cotton swabs that were further reacted with a high concentration $(180 \mathrm{mM})$ of $\mathrm{H}_{2} \mathrm{O}_{2}$ solution $(0.1 \mathrm{~mL})$ at $\mathrm{pH}$. The results from the first step revealed the presence of $E$. coli J96 because the swabs showed a bluish color, whereas the results from the second step indicated the presence of S. aureus, owing to bubble formation. Our method can thus be used for detecting pathogenic bacteria. Furthermore, determining the presence of either Gram-positive bacteria or Gram-negative bacteria is possible by using the two-step method for the results. We took samples directly from the door handles (DH1, DH2, and DH3) of the restroom in our building and determined whether bacteria were present on the samples with our two-step method. Figure $7 \mathrm{C}$ shows the photograph of the resulting three cotton swabs obtained after our method was used on the samples. Apparently, the swabs from DH2 and DH3 became bluish, indicating the presence of Gram-negative bacteria with a 
cell number of $>10^{5}$ (cf. Figure 2A). Figure 7D shows the results obtained after treating the same swabs shown in Figure $7 \mathrm{C}$ with a high concentration of $\mathrm{H}_{2} \mathrm{O}_{2}(180 \mathrm{mM}, 0.1 \mathrm{~mL})$. Apparently, only the swabs from DH1 and DH3 generated visible bubbles, indicating that DH1 and DH3 contained Gram-positive bacteria with a cell number of $>\sim 10^{6}$ cells (cf. Figure 2D). That is, DH1 contained Gram-positive bacteria with a cell number of $>\sim 10^{5}$, whereas DH2 only contained Gram-negative bacteria with a bacterial cell number of $>\sim 10^{6}$. Moreover, DH3 contained Gram-positive and Gram-negative bacteria. To further confirm the presence of bacteria on these door-handle samples, the other cotton swabs were used to collect further samples from these three door handles. SI Figure S7A-C shows the photographs of the agar plate of the cultured samples collected from these three door-handles after incubation for $14 \mathrm{~h}$. Apparently, many bacteria grew on the sample collected from DH1 (SI Figure S7A). More than one type of bacterial colony appeared in the samples collected from DH2 (SI Figure S7B) and DH3 (SI Figure S7C). These results demonstrated that using our two-step method for rapidly detecting pathogenic bacteria with the naked eye is possible.

(A)

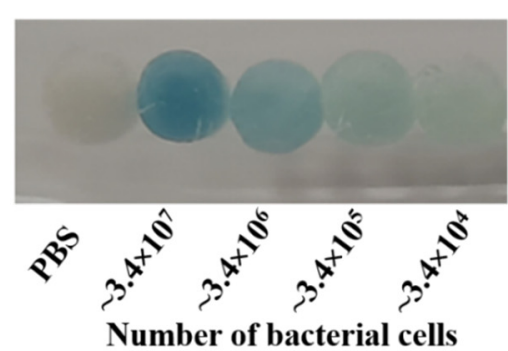

(C)

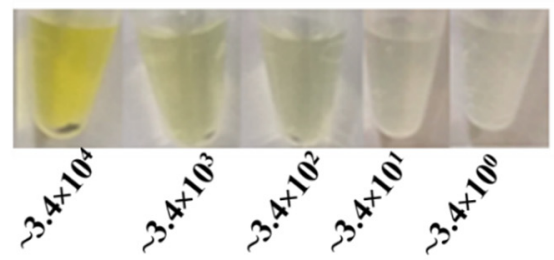

Number of bacterial cells before $4 \mathrm{~h}$ incubation
(B)

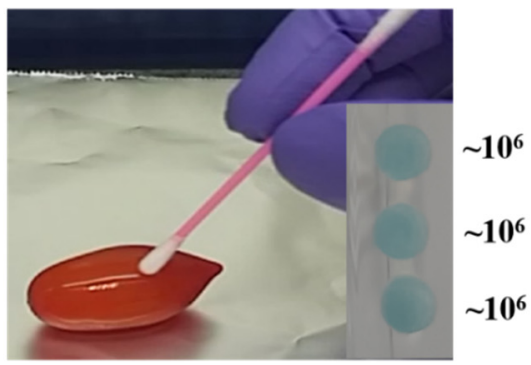

(D)

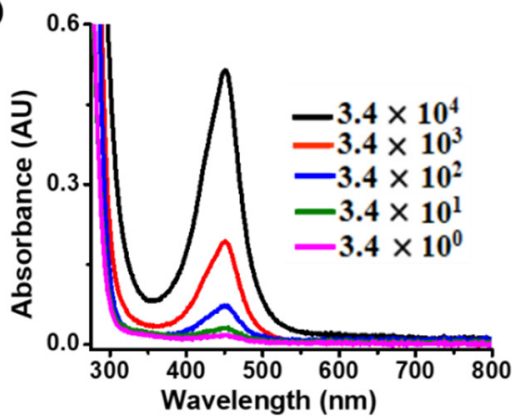

Figure 6. Detection of bacteria from bacterium-contaminated cherry tomatoes. (A) Photograph of the cotton swabs obtained after sampling bacteria from the cherry tomatoes smeared with PBS only, and $\sim 3.4 \times 10^{7}-3.4 \times 10^{4}$ E. coli O157:H7 cells (left to right), followed by dipping into a reagent $(50 \mu \mathrm{L})$ containing $\mathrm{H}_{2} \mathrm{O}_{2}(\sim 11.2 \mathrm{mM})$ and TMB $(1.25 \mathrm{mM})$ at $\mathrm{pH} 3$. (B) Photograph of the as-prepared tomato that was sampled by a cotton swab. The photograph inset on the right-hand side shows the three swabs obtained after sampling bacteria from the surface of three individual tomatoes smeared with $\sim 10^{6}$ cells of E. coli O157:H7, followed by immersion in a reagent droplet $(50 \mu \mathrm{L})$ containing $\mathrm{H}_{2} \mathrm{O}_{2}$ and $\mathrm{TMB}$ at $\mathrm{pH} 3$. (C) Photograph of the samples obtained after collecting bacteria from the cherry tomatoes smeared with $\sim 3.4 \times 10^{4}-\sim 3 \mathrm{E}$. coli O157:H7 cells (left to right), followed by incubation in a growth broth $(0.4 \mathrm{~mL})$ for $4 \mathrm{~h}$ and then reacted with the reagent $(0.2 \mathrm{~mL})$ containing $\mathrm{H}_{2} \mathrm{O}_{2}(\sim 11.2 \mathrm{mM})$ and TMB $(1.25 \mathrm{mM})$ at $\mathrm{pH} 3$, and the addition of sulfuric acid $(2 \mathrm{M}, 2 \mu \mathrm{L})$. (D) The corresponding UV-Vis absorption spectra of the samples obtained in (C). 
(A)

(C)
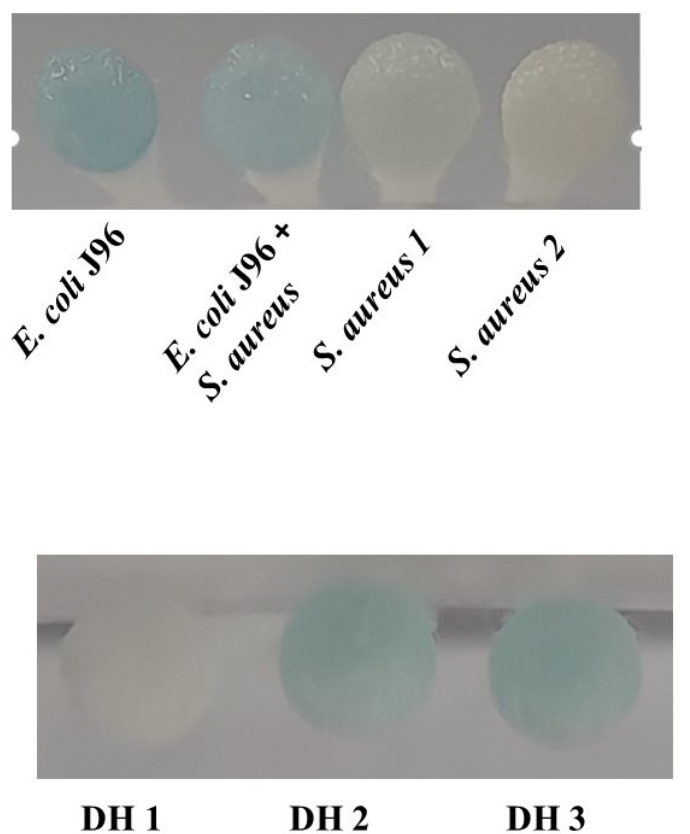

(B)

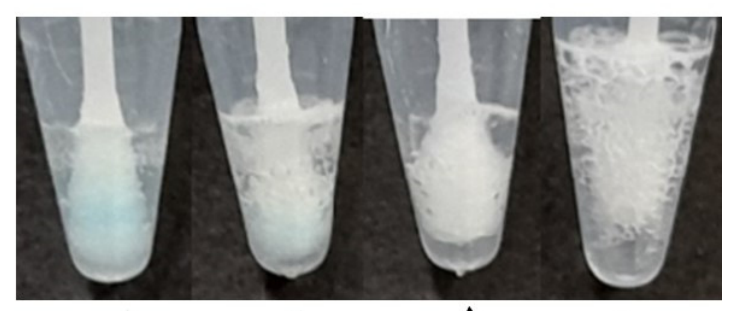

(D)
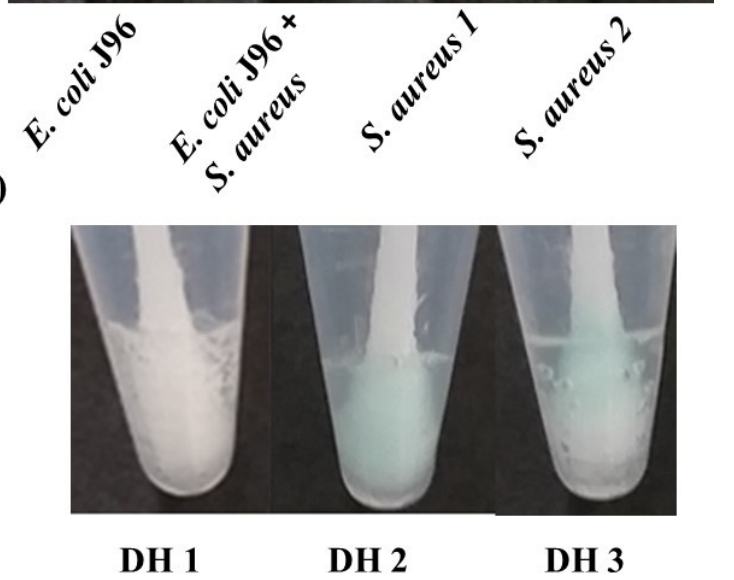

Figure 7. Detection of bacteria from door handles. (A) Photograph of the cotton swabs obtained after sampling bacteria from door handles smeared with the bacterial samples, including E. coli J96 $\left(2.7 \times 10^{5}\right.$ cells), the mixture of E. coli J96 $\left(\sim 2.7 \times 10^{5}\right.$ cells $)$ and $S$. aureus $\left(\sim 8.5 \times 10^{7}\right.$ cells $)$, and two $S$. aureus samples with different cell numbers $\left(\sim 8.5 \times 10^{5}\right.$ cells $(S$. aureus 1 ) and $\sim 8.5 \times 10^{7}$ cells (S. aureus 2$)$ ), followed by dipping into a reagent $(50 \mu \mathrm{L})$ containing $\mathrm{H}_{2} \mathrm{O}_{2}(11.2 \mathrm{mM})$ and TMB (1.25 mM) at pH 3. (B) Photograph of the cotton swabs from Panel A, obtained after further reaction with a reagent containing $\mathrm{H}_{2} \mathrm{O}_{2}(180 \mathrm{mM}, 0.1 \mathrm{~mL})$ at $\mathrm{pH}$ 3. (C) Photograph of the swabs used to collect bacteria from the door handles from the restroom, obtained after reaction with the reagent $(50 \mu \mathrm{L})$ containing TMB $(1.25 \mathrm{mM})$ and $\mathrm{H}_{2} \mathrm{O}_{2}(\sim 11.2 \mathrm{mM})$. (D) Photograph of the cotton swabs from Panel C, obtained after further reaction with $\mathrm{H}_{2} \mathrm{O}_{2}(180 \mathrm{mM}, 0.1 \mathrm{~mL})$ at $\mathrm{pH} 3$.

\section{Conclusions}

Conventional Gram-staining methods for distinguishing Gram-positive from Gramnegative bacteria require freshly harvested bacterial samples. Thus, overnight culture is generally needed for the preparation of bacterial samples. Therefore, rapid identification of Gram-negative or Gram-positive bacteria was limited because of this requirement. A rapid method that can be used in distinguishing Gram-negative bacteria from Grampositive bacteria by exploiting the bacterial endogenous peroxidase or catalase reactions has been successfully demonstrated in this study. The developed method possesses several advantages, including being label-free and offering good sensitivity and high selectivity. Moreover, the developed method has a considerably shorter analysis time than existing methods used for distinguishing Gram-negative bacteria from Gram-positive bacteria, given that overnight culture is not required. Only a cotton swab and a few chemical reagents are sufficient to complete the sensing method. Moreover, the results can be visually assessed without the use of any instrumentation, if the bacterial cell number is higher than $\sim 10^{5}-10^{6}$. However, the developed method can only be used to discriminate between Gram-positive and Gram-negative bacteria. The capacity for identification among different bacteria is insufficient. The method can be further improved by using affinitybased approaches that have the capability to respond to specific bacteria. Nevertheless, owing to its simplicity, the developed method should have the potential for use in realworld applications. On the basis of similar operation principles, the developed method can be potentially extended to applications in rapid diagnostics for discriminating Grampositive and Gram-negative bacteria from bacterium-infected skin or wounds. Given that the antibiotics used to treat infections caused by Gram-positive and Gram-negative bacteria are generally different, minimizing the misuse and overuse of antibiotics is thus possible. Therefore, the speed of emerging of antibiotic-resistant bacterial strains can be reduced. 
Supplementary Materials: The following are available online at https: / www.mdpi.com/article/ 10.3390/bios11090317/s1, Scheme S1: Scheme S1. Enzymatic reactions. Figure S1: Examination of the optimal experimental conditions. Figure S2: Examination of the optimal reaction time. Figure S3: Optimization of the concentration of hydrogen peroxide in the catalase reactions. Figure S4: Examination of endogenous enzymatic reactions of four other model bacteria, Figure S5: Examination of the limit of detection of S. aureus-based endogenous enzymatic reactions, Figure S6: Examination of endogenous enzymatic reactions of the mixture of E. coli and A. niger. Figure S7: Photographs of the agar plates inoculated with the samples collected from door handles.

Author Contributions: Conceptualization, K.K. and Y.-C.C.; Formal analysis, K.K.; Funding acquisition, Y.-C.C.; Investigation, K.K. and M.J.; Methodology, K.K.; Project administration, Y.-C.C.; Resources, Y.-C.C.; Supervision, Y.-C.C.; Validation, M.J. and Y.-C.C.; Writing-original draft, K.K.; Writing-review \& editing, Y.-C.C. All authors have read and agreed to the published version of the manuscript.

Funding: This research was funded by the Ministry of Science and Technology of Taiwan, grant number MOST 108-2113-M-009-018-MY3.

Acknowledgments: We thank the Ministry of Science and Technology of Taiwan (MOST 108-2113M-009-018-MY3) for their financial support of this research. MJ thanks NCTU (NYCU) for providing her with the NCTU Elite scholarship and NYCU foreign student scholarship. We also thank Yu-Xuan Yeh for providing us with the A. niger spores.

Conflicts of Interest: The authors declare no conflict of interest.

\section{References}

1. Bintsis, T. Foodborne pathogens. AIMS Microbiol. 2017, 3, 529. [CrossRef] [PubMed]

2. Mead, P.S.; Slutsker, L.; Dietz, V.; McCaig, L.F.; Bresee, J.S.; Shapiro, C.; Griffin, P.M.; Tauxe, R.V. Food-related illness and death in the United States. Emerg. Infect. Dis. 1999, 5, 607. [CrossRef]

3. FDA. Bad Bug Book, Foodborne Pathogenic Microorganisms and Natural Toxins, 2nd ed.; FDA: Silver Spring, MD, USA, 2012.

4. Boyer, O.; Niaudet, P. Hemolytic uremic syndrome: New developments in pathogenesis and treatment. Int. J. Nephrol. 2011, 2011, 908407. [CrossRef] [PubMed]

5. Luna-Guevara, J.J.; Arenas-Hernandez, M.M.P.; Martínez de la Peña, C.; Silva, J.L.; Luna-Guevara, M.L. The role of pathogenic E. coli in fresh vegetables: Behavior, contamination factors, and preventive measures. Int. J. Microbiol. 2019, $2019,2894328$. [CrossRef]

6. Heiman, K.E.; Mody, R.K.; Johnson, S.D.; Griffin, P.M.; Gould, L.H. Escherichia coli O157 outbreaks in the United States, $2003-2012$. Emerg. Infect. Dis. 2015, 21, 1293-1301. [CrossRef]

7. Nygren, B.L.; Schilling, K.A.; Blanton, E.M.; Silk, B.J.; Cole, D.J.; Mintz, E.D. Foodborne outbreaks of shigellosis in the USA, 1998-2008. Epidemiol. Infect. 2013, 141, 233-241. [CrossRef] [PubMed]

8. Buchanan, R.L.; Gorris, L.G.; Hayman, M.M.; Jackson, T.C.; Whiting, R.C. A review of Listeria monocytogenes: An update on outbreaks, virulence, dose-response, ecology, and risk assessments. Food Control 2017, 75, 1-13. [CrossRef]

9. Camps, N.; Dominguez, A.; Perez, M.; Pardos, J.; Llobet, T.; Usera, M.A.; Salleras, L. A foodborne outbreak of Salmonella infection due to overproduction of egg-containing foods for a festival. Epidemiol. Infect. 2005, 133, 817-822. [CrossRef] [PubMed]

10. Kadariya, J.; Smith, T.C.; Thapaliya, D. Staphylococcus aureus and staphylococcal food-borne disease: An ongoing challenge in public health. Bio. Med. Res. Int. 2014, 2014, 827965.

11. Scallan, E.; Hoekstra, R.M.; Angulo, F.J.; Tauxe, R.V.; Widdowson, M.A.; Roy, S.L.; Jones, J.L.; Griffin, P.M. Foodborne illness acquired in the United States-major pathogens. Emerg. Infect. Dis. 2011, 17, 7-15. [CrossRef]

12. Denis, N.; Zhang, H.; Leroux, A.; Trudel, R.; Bietlot, H. Prevalence and trends of bacterial contamination in fresh fruits and vegetables sold at retail in Canada. Food Control 2016, 67, 225-234. [CrossRef]

13. Matthysse, A.G. Adherence of bacteria to plant surfaces measured in the laboratory. J. Vis. Exp. 2018, 136, e56599. [CrossRef] [PubMed]

14. Centers for Disease Control and Prevention National Health Interview Durvey [Data Set]. Available online: http:/ /www.cdc. gov / foodborneburden/2011-foodborne-estimates.html (accessed on 3 May 2021).

15. Argudín, M.Á.; Mendoza, M.C.; Rodicio, M.R. Food poisoning and Staphylococcus aureus enterotoxins. Toxins 2010, 2, 1751-1773. [CrossRef] [PubMed]

16. Sarowska, J.; Futoma-Koloch, B.; Jama-Kmiecik, A.; Frej-Madrzak, M.; Ksiazczyk, M.; Bugla-Ploskonska, G.; Choroszy-Krol, I. Virulence factors, prevalence and potential transmission of extraintestinal pathogenic Escherichia coli isolated from different sources: Recent reports. Gut Pathog. 2019, 11, 1-16. [CrossRef] [PubMed]

17. Otto, M. Staphylococcus aureus toxins. Curr. Opin. Microbiol. 2014, 17, 32-37. [CrossRef]

18. Bloom, D.E.; Cadarette, D. Infectious disease threats in the twenty-first century: Strengthening the global response. Front. Immunol. 2019, 10, 549. [CrossRef] 
19. Käferstein, F.K.; Motarjemi, Y.; Bettcher, D.W. Foodborne disease control: A transnational challenge. Emerg. Infect. Dis. 1997, 3, 503-510. [CrossRef]

20. Maugeri, G.; Lychko, I.; Sobral, R.; Roque, A.C. Identification and antibiotic-susceptibility profiling of infectious bacterial agents: A review of current and future trends. Biotechnol. J. 2019, 14, 1700750. [CrossRef]

21. Tong, C.; Li, L.; Xiao, F.; Fan, J.; Zhong, X.; Liu, X.; Liu, B.; Wu, Z.; Zhou, J. Daptomycin and AgNP co-loaded rGO nanocomposites for specific treatment of Gram-positive bacterial infection in vitro and in vivo. Biomater. Sci. 2019, 7, 5097-5111. [CrossRef]

22. Claeys, K.C.; Heil, E.L.; Pogue, J.M.; Lephart, P.R.; Johnson, J.K. The Verigene dilemma: Gram-negative polymicrobial bloodstream infections and clinical decision making. Diagn. Microbiol. Infect. Dis. 2018, 91, 144-146. [CrossRef]

23. Bu, S.J.; Wang, K.Y.; Bai, H.S.; Leng, Y.; Ju, C.J.; Wang, C.Y.; Liu, W.S.; Wan, J.Y. Immunoassay for pathogenic bacteria using platinum nanoparticles and a hand-held hydrogen detector as transducer. Application to the detection of Escherichia coli O157: H7. Microchim. Acta 2019, 186, 296. [CrossRef]

24. Ouyang, Z.; Zhai, Z.; Qin, A.N.; Li, H.; Liu, X.; Qu, X.; Dai, K. Limitations of Gram staining for the diagnosis of infections following total hip or knee arthroplasty. Exp. Ther. Med. 2015, 9, 1857-1864. [CrossRef] [PubMed]

25. Froböse, N.J.; Bjedov, S.; Schuler, F.; Kahl, B.C.; Kampmeier, S.; Schaumburg, F. Gram staining: A comparison of two automated systems and manual staining. J. Clin. Microbiol. 2020, 58, e01914-20. [CrossRef] [PubMed]

26. Bazzi, A.M.; Al-Tawfiq, J.A.; Rabaan, A.A. Misinterpretation of gram stain from the stationary growth phase of positive blood cultures for Brucella and Acinetobacter species. Open Microbiol. J. 2017, 11, 126-131. [CrossRef]

27. Nóbrega, C.S.; Pauleta, S.R. Reduction of 0.2 in gram-negative bacteria-bacterial peroxidases. Adv. Microb. Physiol. 2019, 74, 415-464.

28. Ramasamy, M.; Yi, D.K.; An, S.S.A. Enhanced detection sensitivity of Escherichia coli O157: H7 using surface-modified gold nanorods. Int. J. Nanomed. 2015, 10, 179-190.

29. Wang, X.; Yang, Y.; Li, L.; Sun, M.; Yin, H.; Qin, W. A polymeric liquid membrane electrode responsive to 3, 3', 5, 5' tetramethylbenzidine oxidation for sensitive peroxidase/peroxidase mimetic-based potentiometric biosensing. Anal. Chem. 2014, 86, 4416-4422. [CrossRef]

30. Frey, A.; Meckelein, B.; Externest, D.; Schmidt, M.A. A stable and highly sensitive 3, 3' , 5, 5' -tetramethylbenzidine-based substrate reagent for enzyme-linked immunosorbent assays. J. Immunol. Methods 2009, 233, 47-56. [CrossRef]

31. John Goka, A.K.; Farthing, M.J. The use of 3, 3' , 5, 5' -tetramethylbenzidine as a peroxidase substrate in microplate enzyme-linked immunosorbent assay. J. Immunoass. 1987, 8, 29-41. [CrossRef]

32. Chen, Y.; Zhong, Q.; Wang, Y.; Yuan, C.; Qin, X.; Xu, Y. Colorimetric detection of $\mathrm{H}_{2} \mathrm{O}_{2}$ and glucose by exploiting the peroxidaselike activity of papain. RSC Adv. 2019, 9, 16566-16570. [CrossRef]

33. Shim, K.H.; Kang, M.; Kim, M.G.; Chung, B.H.; An, S.S.A. Detection of E. coli O157: H7 using its endogenous active membrane peroxidase. J. Toxicol. Environ. 2011, 3, 80-85. [CrossRef]

34. Shenge, K.C.; Whong, C.M.; Yakubu, L.L.; Omolehin, R.A.; Erbaugh, J.; Miller, S.A.; LeJeune, J.T. Contamination of tomatoes with coliforms and Escherichia coli on farms and in markets of northwest Nigeria. J. Food Prot. 2015, 78, 57-64. [CrossRef]

35. Obeng, F.A.; Gyasi, P.B.; Olu-Taiwo, M.; Ayeh-Kumi, F.P. Microbial assessment of tomatoes (Lycopersicon esculentum) sold at some central markets in ghana. Bio. Med. Res. Int. 2018, 3, 1-7. [CrossRef] [PubMed]

36. Jeddi, M.Z.; Yunesian, M.; Gorji, M.E.H.; Noori, N.; Pourmand, M.R.; Khaniki, G.R.J. Microbial evaluation of fresh, minimallyprocessed vegetables and bagged sprouts from chain supermarkets. J. Health Popul. Nutr. 2014, 32, 391-399.

37. Gaupp, R.; Ledala, N.; Somerville, G.A. Staphylococcal response to oxidative stress. Front. Cell. Infect. Microbiol. 2012, 2, 1-19. [CrossRef] [PubMed]

38. Bukhari, Z.; Weihe, J.; LeChevallier, M. Development of procedures for rapid detection of E. coli O157: H7 from source and finished water samples. Water Sci. Technol. 2004, 50, 33-237. [CrossRef]

39. Bonham, P.A. Swab cultures for diagnosing wound infections: A literature review and clinical guideline. J. Wound Ostomy Cont. Nurs. 2009, 36, 389-395. [CrossRef]

40. Seaver, L.C.; Imlay, J.A. $\mathrm{H}_{2} \mathrm{O}_{2}$ fluxes and compartmentalization inside growing Escherichia coli. J. Bacteriol. 2001, 183, 7182-7189. [CrossRef] [PubMed]

41. Raffellini, S.; Guerrero, S.; Alzamora, S.M. Effect of $\mathrm{H}_{2} \mathrm{O}_{2}$ concentration and $\mathrm{pH}$ on inactivation kinetics of Escherichia coli. J. Food Saf. 2008, 28, 514-533. [CrossRef]

42. Seaver, L.C.; Imlay, J.A. Alkyl hydroperoxide reductase is the primary scavenger of endogenous $\mathrm{H}_{2} \mathrm{O}_{2}$ in Escherichia coli. J. Bacteriol. 2001, 183, 7173-7181. [CrossRef]

43. Frankenberg, L.; Brugna, M.; Hederstedt, L. Enterococcus faecalis heme-dependent Catalase. J. Bacteriol. 2002, 184, 6351-6356. [CrossRef] [PubMed]

44. Kikuchi-Torii, K.; Hayashi, S.; Nakamoto, H.; Nakamura, S. Properties of Aspergillus niger catalase. J. Biochem. 1982, 92, 1449-1456. [CrossRef] [PubMed]

45. Gibson, B.; Wilson, D.J.; Feil, E.; Eyre-Walker, A. The distribution of bacterial doubling times in the wild. Proc. Biol. Sci. 2018, 285, 20180789. [CrossRef] [PubMed] 